\title{
PERBEDAAN PERKEMBANGAN SOSIAL ANAK USIA 3-6 TAHUN DENGAN PENDIDIKAN USIA DINI DAN TANPA PENDIDIKAN USIA DINI DI KECAMATAN PETERONGAN JOMBANG
}

\author{
THE DIFFERENCES IN SOCIAL DEVELOPMENT OF CHILDREN AGES 3-6 YEARS \\ BETWEEN EARLY AGE EDUCATION AND WITHOUT AGE EARLY EDUCATION IN \\ DISTRICT PETERONGAN, JOMBANG
}

Retno Wulandari, Burhannudin Ichsan, Yusuf Alam Romadhon

Fakultas Kedokteran Universitas Muhammadiyah Surakarta

Korespondensi: dr. Burhannudin Ichsan,MMed,MKes, Email: Burhannudin.Ichsan@ums.ac.id

\begin{abstract}
ABSTRAK
Pertumbuhan dan perkembangan anak dipengaruhi oleh banyakfaktor diantaranya stimulasi perkembangan dan faktor lingkungan dari anak. Pendidikan anak usia dini merupakan suatu bentuk stimulasi yang pada dasarnya adalah upaya-upaya intervensi yaitu menciptakan lingkungan sekitar anak usia dini agar mampu menstimulasi seluruh aspek perkembangan anak. Penelitian ini observasional analitik, dengan pendekatan cross sectional. Pengambilan sampel dengan teknik random sample (probability samples) dengan pendekatan cluster sampling. Uji statistik yang digunakan uji Chi-Square (nilai expected $<5$, maksimal 20\% dari jumlah sel). Terdapat perbedaan perkembangan sosial pada anak usia 3-6 tahun dengan pendidikan usia dini dan tanpa pendidikan usia dini secara signifikan (p.0,002). Kesimpulan: Terdapat perbedaan yang signifikan antara perkembangan sosial pada anak usia 3-6 tahun dengan pendidikan usia dini dan tanpa pendidikan usia dini di Kecamatan Peterongan Jombang.
\end{abstract}

Kata kunci.Perkembangan sosial, pendidikan usia dini, anak usia 3-6 tahun

\section{ABSTRACT}

Growth and development of children is influenced by many factors, including the stimulation of the development of the child and environmental factors. Early childhood education is a form of stimulation that is basically intervention efforts that create the environment for early childhood in order to stimulate all aspects of child development.This study was observational analytic with cross sectional approach. The sampling technique of random sample (probability samples) with a cluster sampling approach. The used statistical test Chi-Square test (expected values $<5$, maximal 20\% of the number of cells). There are differences in social development in children aged 3-6 years with early education and without early education significantly (p. 0.002). Conclusion: There are significant differences between social development in children aged 3-6 years old with early childhood education and without early childhood education in Peterongan Sub district Jombang.

Keywords. Social development, early childhood education, children aged 3-6 years

\section{PENDAHULUAN}

Perkembangan secara termitologis adalah proses kualitatif yang mengacu pada penyempurnaan fungsi sosial dan psikologis dalam diri seseorang dan berlangsung sepanjang hidup (Ikalor, 2013).Manusia dalam perkembangannya melalui beberapa tahapan. Tahapan yang harus dilalui manusia dan sangat berpengaruh terhadap manusia baik secara fisik maupun secara psikologis adalah masa anak-anak, karena pada masa anakanak ini adalah sebagai pondasi (Halimah \& Kawuryan, 2010).
Perkembangan anak pada usia dini disebut sebagai masa emas "Golden Age" yang artinya perkembangan pada usia ini sangat berpengaruh terhadap perkembangan pada periode berikutnya hingga anak menjadi dewasa (Sulistiani, 2009). Usia 0-6 tahun adalah usia yang sangat menentukan dalam pembentukan karakter baik sikap, perilaku, dan kepribadian seorang anak di masa depan (Dorlina, 2011). Umumnya pada tahap ini anak usia dini belajar mengenai berbagai hal termasuk dalam mengembangkan kemampuan motorik, kognitif, bahasa, serta sosioemosional mereka (Mayar, 2013). 
Masa balita juga sebagai periode emas bagi orangtua untuk mengembangkan potensi anak secara optimal. Pada masa balita hampir seluruh sel-sel otak berkembang pesat. Tidak ada orang yang paling berarti dalam kehidupan seorang balita selain orangtuanya yang dapat memenuhi segala pertumbuhan dan perkembangannya. Kemampuan orangtua dalam memenuhi kebutuhan akan asuh, asih, dan asah akan mempengaruhi mutu kepribadian anak di kemudian hari $(\mathrm{BKKBN}$, 2014).

Pertumbuhan dan perkembangan anak dipengaruhi oleh banyak faktor diantaranya pendidikan ibu, pekerjaan ibu, pendidikan bapak, stimulasi perkembangan dan faktor lingkungan dari anak (Ardita dkk, 2012). Meadow menyatakan bahwa lingkungan akan mempengaruhi anak dalam berbagai hal, antara lain akan berpengaruh terhadap bagaimana seorang anak berkembang dan belajar dari lingkungan (Martani, 2012).

Pendidikan anak usia dini merupakan suatu bentuk stimulasi yang pada dasarnya adalah upaya intervensi yaitu menciptakan lingkungan sekitar anak usia dini agar mampu menstimulasi seluruh aspek perkembangan anak. Mashar menyatakan bahwa anak yang mengalami hambatan ataupun problema perkembangan, tidak akan berkembang secara optimal (Martani, 2012).

Pendidikan anak pada usia dini telah menjadi perhatian para orangtua, ahli pendidikan, dan pemerintah. Pendidikan pada usia dini bermanfaat mengembangkan berbagai kompetensi anak usia dini termasuk kompetensi sosial. Kompetensi sosial adalah kemampuan seseorang untuk berhubungan dengan orang lain. Kompetensi sosial pada anak usia dini terdiri dari karakter individu, keterampilan sosial, hubungan dengan teman sebaya, dan hubungan dengan orang dewasa (Siti, 2012). Banyak permasalahan yang muncul pada perilaku anak usia dini. Permasalahan tentang perilaku yang mencakup perkembangan sosial, emosi, dan moral ialah perilaku antisosial. Perilaku antisosial ini saat ini sering kita jumpai dan ada pula yang terlihat pada anak usia dini. Perilaku antisosial ini akan menjadi permasalahan yang komplek pada anak dan akan berdampak pada perilaku agresif. Orangtua berharap bahwa di Taman Kanak-kanak (TK) anak akan mendapatkan stimulasi yang memadai bagi perkembangan anak. Lingkungan belajar diluar rumah atau di TK, anak akan belajar dan mendapat stimulasi (Martani, 2012).

Pendidikan anak usia dini (PAUD) adalah suatu upaya pembinaan yang ditujukan bagi anak sejak lahir sampai dengan usia enam tahun yang dilakukan dengan pemberian rangsangan pendidikan untuk membantu pertumbuhan dan perkembangan jasmani dan rohani agar anak memiliki kesiapan dalam memasuki pendidikan lebih lanjut. Pendidikan Anak Usia Dini (PAUD) justru belum banyak mendapat perhatian. Pendidikan usia dini baru diperoleh oleh sebagian kecil anak di Indonesia. Pendataan Depdiknas pada tahun 2002, baru 28 persen dari 26,1 juta anak usia 6 tahun yang mendapat pendidikan usia dini. Sebagian besar di antara mereka, yakni 2,6 juta, mendapatkan pendidikan dengan jalan masuk ke Sekolah Dasar pada usia lebih awal (Enung, 2006). Indonesia memiliki fasilitas PAUD yang relatif sedikit. Situasi yang seperti ini menjelaskan mengapa orangtua cenderung untuk menyekolahkan anak-anak mereka lebih awal, sekitar 72 persen anak usia enam tahun telah terdaftar di kelas 1 Sekolah Dasar (UNICEF Indonesia, 2012). Sebanyak 2,5 juta anak mendapat pendidikan di Bina Keluarga Balita (BKB), 2,1 juta anak bersekolah di TK atau Raidhatul Atfhal, dan sekitar 100.000 anak di kelompok bermain (play group). Rasio jumlah lembaga pendidikan dan anak usia dini diperkirakan 1:8. Data tersebut memperlihatkan bahwa Pendidikan Anak Usia Dini (PAUD) belum cukup mendapatkan perhatian padahal kapasitas perkembangan kognitif anak sudah dapat terbentuk pada usia dini jauh dibawah usia sekolah (Enung, 2006). Akses dan kualitas pelayanan PAUD sangat tidak seimbang, menurut UNICEF Indonesia (2012) menyampaikan kirakira 62 persen anak usia 3 sampai 6 tahun belum pernah berpartisipasi dalam program pendidikan anak usia dini atau prasekolah. Tahun 2009, proporsi anak perkotaan yang mengikuti beberapa bentuk program PAUD dua kali lipat dari proporsi anak pedesaan.

Balita di Indonesia sangat besar yaitu sekitar 10 persen dari seluruh populasi. Calon generasi penerus bangsa perlu mendapat perhatian yang serius. Stimulasi yang memadai artinya merangsang otak balita sehingga perkembangan kemampuan gerak, bicara, dan bahasa, sosialisasi dan kemandirian pada balita dapat berlangsung 
secara optimal sesuai umur anak (Depkes RI, 2007). Perkembangan sosial mengacu pada perilaku anak dalam hubungannya dengan lingkungan sosial agar mandiri dan dapat berinteraksi untuk menjadi manusia sosial. Kemandirian adalah salah satu komponen dari kecerdasan emosional. Para ahli pendidikan dan psikolog berpendapat bahwa kemandirian menentukan keberhasilan dalam kehidupan seseorang (Retnowati, 2008).

Pemeriksaan tumbuh kembang di Jawa Timur pada tahun 2010 telah dilakukan pada 2.321.542 anak balita dan prasekolah atau $63,48 \%$ dari 3.657.353 anak balita. Cakupan tersebut menurun dibandingkan tahun 2009 sebesar $64,03 \%$ dan masih dibawah target $80 \%$, perlu perbaikan agar dapat diperbaiki apabila terjadi masalah atau keterlambatan tumbuh kembang pada anak prasekolah (Dinas Kesehatan Provinsi Jawa Timur, 2011). Pemantauan tersebut harus dilakukaan secara teratur dan berkesinambungan. Sedini mungkin pemantauan dapat dilakukan oleh orangtua. Pemantauan juga dapat dilakukan oleh masyarakat melalui kegiatan posyandu dan oleh guru di sekolah. Pengetahuan tentang deteksi dini pertumbuhan dan perkembangan anak perlu dimiliki oleh orangtua, guru, dan masyarakat (Chamida, 2012).

Permasalahan perilaku anak tidak terlepas dari proses sosialisasi anak. Perkembangan sosial diperoleh anak melalui kematangan dan kesempatan belajar dari berbagai stimulus dari lingkungan anak. Perilaku sosial merupakan aktivitas yang berkaitan dengan orang lain, baik dengan teman sebaya, guru, orangtua maupun saudara. Perilaku sosial yang dibina pada awal masa kanak-kanak sangat menentukan kepribadiannya.Dengan melakukan penelitian ini, diharapkan dapat memberikan wawasan yang bermanfaat secara nasional maupun global.

Penelitian ini bertujuan untuk menganalisis perbedaan perkembangan sosial anak usia 3-6 tahun dengan pendidikan usia dini dan tanpa pendidikan usia dini di Kecamatan Peterongan Jombang.

\section{METODE}

Penelitian ini menggunakan rancangan observasional analitik dengan pendekatan cross sectional. Data yang menyangkut Pendidikan
Usia Dini dan perkembangan sosial anak diukur sekaligus pada suatu saat(Notoatmodjo, 2012). Sampel dari penelitian ini adalah anak usia 3-6 tahun dengan pendidikan usia dini dan tanpa pendidikan usia dini.Teknik pegambilan sampel dilakukan dengan cluster random sampling. Besar sampel dihitung dengan menggunakan rumus besar sampel untuk penelitian analitik kategorik tidak berpasangan dan ditemukan masing-masing kelompok 31 anak. Untuk menghindari adanya drop out saat penelitian masing-masing sampel ditambah oleh peneliti sebesar $10 \%$ sehingga total sampel menjadi 68(Dahlan, 2013).

Kriteria inklusi dari penelitian ini yaitu anak usia 3-6 tahun dengan pendidikan usia dini dan tanpa pendidikan usia dini di wilayah kerja Pukesmas Dukuhklopo Kecamatan Peterongan Jombang, sedangkan kriteria eksklusinya yaitu : a) anak dengan sakit berat, b) anak yang cacat lahir, c) anak menderita infeksi kronis, dan d) orang tua yang menolak anak diikutkan penelitian. Pendidikan Usia Dini yang dimaksud dalam penelitian ini adalah aspek sosial anak yang mengikuti PAUD dan tidak mengikuti PAUD pada usia 3-6 tahun.Penilaian dilakukan dengan metode dokumentasi dengan mencari data anak yang mengikuti kegiatan pendidikan di luar rumah (PAUD) dan data anak dengan kegiatan pendidikan dari lingkungan rumah.Perilaku sosial merupakan aktivitas yang berkaitan dengan orang lain, baik dengan teman sebaya, guru, orang tua maupun saudara. Penilaian perkembangan sosial menggunakan Denver Developmental Screening Test II (DDST II) dengan kategori sesuai dan tidak sesuai. Penelitian dilaksanakan di wiayah kerja Puskesmas Dukuhklopo Kecamatan Peterongan Jombang yang dilaksanakan pada bulan Desember 2015 .

\section{HASIL DAN PEMBAHASAN}

Hasil analisis univariat adalah sebagai berikut:

Tabel 1. Distribusi Sampel Berdasarkan Usia

\begin{tabular}{lcc}
\hline \multicolumn{1}{c}{ Usia } & Jumlah & Presentase \\
\hline 3 Tahun & 17 & $25 \%$ \\
4 Tahun & 27 & $39,7 \%$ \\
5 Tahun & 19 & $27,9 \%$ \\
6 Tahun & 5 & $7,4 \%$ \\
Total & 68 & $100 \%$ \\
\hline
\end{tabular}


Tabel 2. Distribusi Sampel Berdasarkan Jenis Kelamin

\begin{tabular}{lcc}
\hline Jenis Kelamin & Jumlah & Presentase \\
\hline Laki-laki & 41 & $60,3 \%$ \\
Perempuan & 27 & $39,7 \%$ \\
Total & 68 & $100 \%$ \\
\hline
\end{tabular}

Hasil analisis bivariat adalah sebagai berikut

Tabel 3. Hasil Uji Chi-Square Perbedaan Perkembangan Sosial Anak-anak yang mengikuti PAUD dan tidak

\begin{tabular}{lccccccc}
\hline \multirow{2}{*}{ Perkembangan Sosial } & \multicolumn{2}{c}{ Sesuai } & \multicolumn{2}{c}{ Tidak Sesuai } & Total & Presentase & \multirow{2}{*}{$\mathrm{P}$} \\
\cline { 2 - 5 } & $\mathrm{N}$ & $\%$ & $\mathrm{~N}$ & $\%$ & $\mathrm{~N}$ & $\%$ & \\
\hline PAUD & 22 & 64,7 & 12 & 35,3 & 34 & $100,0 \%$ & \\
Tidak PAUD & 9 & 26,5 & 25 & 73,5 & 34 & $100,0 \%$ & 0,002 \\
Jumlah & 31 & 45,6 & 37 & 54,4 & 68 & $100,0 \%$ & \\
\hline
\end{tabular}

Berdasarkan tabel 3 menunjukkan bahwa anak yang mengikuti PAUD dan memiliki perkembangan sesuai sebanyak 22 anak $(64,7 \%)$ dan memiliki perkembangan menyimpang atau tidak sesuai sebanyak 12 anak $(35,3 \%)$. Pada anak yang tidak mengikuti PAUD dan memiliki perkembangan yang sesuai sebanyak 9 anak $(26,5 \%)$ dan menyimpang atau tidak sesuai sebanyak 25 anak (73,5\%).

Berdasarkan uji Chi-Square didapatkan nilai $\mathrm{p}$ sebesar 0,002 atau $\mathrm{p}<0,05$. Penelitian yang dilakukan terhadap 68 anak yang berusia antara 3-6 tahun di wilayah kerja Puskesmas Dukuhklopo Kecamatan Peterongan Jombang menunjukkan bahwa perkembangan sosial yang sesuai pada kelompok anak usia 3-6 tahun dengan pendidikan usia dini jauh lebih banyak sekitar 22 anak $(64,7 \%)$ dibandingkan dengan perkembangan sosial yang sesuai pada kelompok anak usia 3-6 tahun tanpa pendidikan usia dini sekitar 9 anak (26,5\%). Sedangkan perkembangan sosial yang tidak sesuai pada kelompok anak usia 3-6 tahun dengan pendidikan usia dini jauh lebih sedikit sekitar 12 anak (35,5\%) dibandingkan dengan perkembangan sosial yang tidak sesuai pada kelompok anak usia 3-6 tahun tanpa pendidikan anak usia dini sekitar 25 anak (73,5\%). Hasil tersebut dibuktikan dengan menggunakan $\mathrm{Chi}$ Square didapatkan nilai p sebesar $0,002(\mathrm{p}<0,05)$. Hasil analisis tersebut dapat disimpulkan terdapat perbedaan yang bermakna antara perkembangan sosial pada anak usia 3-6 tahun dengan pendidikan usia dini dan tanpa pendidikan usia dini di Kecamatan Peterongan Jombang.
Hasil data analisis univariat menunjukkan distribusi berdasarkan usia anak 3-6 tahun di desa Dukuhklopo, anak usia prasekolah dari Rencana Kerja Pembangunan Daerah (RKPD) Kabupaten Jombang Tahun 2015diperoleh jumlah penduduk di Kabupaten Jombang menurut kelompok usia anak 0-4 tahun berjumlah 53.655 jiwa untuk laki-laki dan perempuan berjumlah 50.976 jiwa dengan total anak usia 0-4 tahun di Jombang sebanyak 104.631 jiwa. Kelompok usia 5-9 tahun berjumlah 50.092 jiwa untuk laki-laki dan perempuan berjumlah 47.804 jiwa dengan total anak usia 5-9 tahun di Jombang terbanyak yaitu 97.869 jiwa. Dalam distribusi tersebut didapatkan anak usia 6 tahun yang harusnya masih mengikuti program PAUD hanya didapatkan sebanyak 5 (7,4\%), hal ini karena Indonesia memiliki program PAUD yang relatif sedikit. Situasi yang seperti ini menjelaskan mengapa orangtua lebih cenderung untuk menyekolahkan anak-anak mereka di Sekolah Dasar lebih awal, sekitar 72 persen anak usia 6 tahun telah terdaftar di kelas 1 Sekolah Dasar (UNICEF, 2012).

Ditribusi untuk perkembangan sosial, jumlah sampel terbanyak untuk sampel perkembangan sosial yaitu perkembangan sosial tidak sesuai sebanyak 37 sampel $(54,4 \%)$ dan perkembangan sosial sesuai sebanyak 31 sampel (45,6\%). Hasil Penelitian Darsana (2012) di Bali yang menyatakan bahwa Perkembangan anak akan optimal bila interaksi sosial diusahakan sesuai dengan kebutuhan anak pada berbagai tahap perkembanganya. Dalam perkembangan anak terdapat masa kritis yang diperlukan 
rangsangan atau stimulasi yang berguna agar potensi berkembang, sehingga perlu mendapatkan perhatian. Kegiatan stimulasi, deteksi dan intervensi dini penyimpangan tumbuh kembang yang menyeluruh dan terkoordinasi diselenggarakan dalam bentuk kemitraan atau kerjasama antara keluarga, dengan tenaga profesional (kesehatan, pendidikan dan sosial) akan meningkatkan tumbuh kembang anak usia dini dan kesiapan memasuki jenjang pendidikan formal (Kusbiantoro, 2015). Tingginya angka keterlambatan yang ditemukan merupakan potensi untuk menurunkan kualitas hidup di kemudian hari sehingga perlu diupayakan bagaimana cara mengatasinya.

Delfita(2011)menyatakan tujuan pendidikan anak usia dini yaitu : 1) memberikan pengasuhan dan pembimbingan yang memungkinkan anak agar tumbuh dan berkembang sesuai dengan usia dan potensinya, 2). mengidentifikasi penyimpangan yang mungkin terjadi, sehingga jika terjadi penyimpangan dapat dilakukan intervensi dini segera, 3) menyediakan pengalaman yang beraneka ragam dan mengundang minat bagi anak usia dini, yang memungkinkan mereka mengembangkan potensi dalam berbagai bidang, sehingga siap untuk mengikuti pendidikan formal, 4) membangun landasan bagi perkembangan potensi peserta didik agar menjadi manusia beriman dan bertaqwa kepada Tuhan Yang Maha Esa, 5) mengembangkan potensi kecerdasan spiritual, intelektual, emosional, dan sosial peserta didik pada masa emas pertumbuhannya dalam lingkungan bermain yang edukatif dan menyenangkan.

Menurut Diana (2010),faktor yang mempengaruhi perkembangan anak secara keseluruhan yaitu faktor gizi (nutrisi) berpengaruh terhadap struktur anatomi otak yang mempengaruhi sel syaraf, faktor infeksi penyakit yang disebabkan oleh kuman penyakit (bakteri, virus, ricketsia, jamur, cacing dan sebagainya), faktor pola pengasuhan anak berupa sikap dan perilaku Ibu atau pengasuh lain dalam hal kedekatannya dengan anak (memberikan makan, merawat, kebersihan, memberi kasih sayang dan sebagainya). Faktor yang mempengaruhi perkembangan sosial anak usia dini menurut Mayar(2013) : 1) faktor lingkungan keluarga, 2) faktor dari luar rumah, dan 3) faktor pengaruh pengalaman sosial anak.
Penelitian yang dilakukan oleh Setyaningrum et al, (2014) membuktikan bahwa anak yang mengikuti pembelajaran di PAUD berpeluang mempunyai perkembangan kognitif baik hampir empat kali dibandingkan anak yang tidak ikut pembelajaran di PAUD. Penelitian dari Hastuti et al, Alfiasari, \& Chandriyani (2010) juga membuktikan bahwa pemberian stimulasi psikososial yang optimal kepada anak akan meningkatkan perkembangan kognitif anak. Didukung dengan penelitian yang dilakukan oleh Gultiano\& King (2006) di Philipina membuktikan bahwa terjadi peningkatan perkembangan psikososial sebesar 6 - 11\% pada anak usia 0-4 tahun yang dilakukan stimulasi selama 2 tahun terhadap 7 domain yang diukur dengan instrument Revised Early Childhood Devolopment Checklist (REC), yaitu : Gross motor, fine motor, self help, receptive language, expressive language, cognitive, socialemotional. Penelitian yang dilakukan oleh UNICEF Indonesia pada tahun 2012 membuktikan hasil studi tentang kesiapan bersekolah di enam Kabupaten di Indonesia menunjukkan bahwa program-program PAUD telah membantu mengembangkan kompetensi psikososial dan kognitif.

Kualitas PAUD di Indonesia belum dapat diukur karena belum pernah ada penelitian tentang ini sebelumnya. Dalam membimbing dan mendidik anak usia dini, guru perlu memiliki berbagai macam kompetensi yaitu kompetensi pedagogik, kompetensi profesional, kompetensi kepribadian dan kompetensi sosial. Penelitian dari Novianti et al, Puspitasari, \& Chairilsyah (2012) di Kota Pekanbaru masih banyak guru PAUD yang tidak memahami prinsip-prinsip dalam melakukan asesmen pada anak usia dini. Dengan demikian apabila guru PAUD tidak memiliki kompetensi dalam melaksanakan asesmen maka sulit untuk mengetahui tingkat perkembangan anak yaitu apakah anak berkembang sesuai harapan atau sebaliknya mengalami keterlambatan perkembangan, akibatnya guru tidak dapat memberikan layanan pendidikan sesuai dengan kebutuhan tiap anak, selain itu guru juga akan sulit merancang pembelajaran yang dapat mengoptimalkan perkembangan anak. Untuk itu Pemerintah harusnya lebih memperhatikan standar tenaga pendidik yang sesuai dengan kurikulum pada program Pendidikan Anak Usia Dini. 
Dinas Pendidikan setempat disarankan untuk melakukan sosialisasi kepada keluarga mengenai pentingnya keikutsertaan anak dalam pendidikan prasekolah. Hal serupa juga ditujukan kepada pengasuh dalam kelompok BKB (Bina Keluarga Balita), Posyandu, dan Pos PAUD yang berperan banyak untuk menyebarluaskan dan menginformasikan kepada keluarga mengenai pentingnya anak mengikuti pendidikan prasekolah dengan menyebarkan leaflet, mengunjungi ke rumah-rumah keluarga dan menjadikan agenda rutin setiap bulan dalam Posyandu. Selain itu, mengingat stimulasi psikososial berpengaruh terhadap perkembangan kognitif anak maka disarankan kepada keluarga untuk memberikan stimulasi yang maksimal kepada anak. Jika dalam pemberian stimulasi terbentur oleh dana disarankan untuk meningkatkan aktivitas ibu dan anak, ibu lebih terlibat dalam pengasuhan (bermain bersama anak, pergi bersama anak), serta memberikan kehangatan dan penerimaan kepada anak serta memberikan teladan kepada anak. Hal ini mengindikasikan pentingnya pendidikan parenting untuk ibu mengenai bagaimana memberikan stimulasi kepada anak yang dapat dilakukan oleh koordinasi tim penggerak PKK dan Kelompok PAUD. Penelitian di Amerika Serikat menunjukkan bahwa anak yang tidak banyak distimulasi maka otaknya akan lebih kecil 30 persen dibandingkan anak lain yang mendapatkan rangsangan secara optimal. Untuk itu diperlukan penilaian terhadap perkembangan anak agar gangguan terhadap perkembangan anak dapat diketahui lebih cepat (Diana, 2010).

Penelitian ini mempunyai kelebihan dimana sampel yang digunakan sudah memenuhi kriteria dan sudah memenuhi target.Penelitian ini juga sederhana dan ekonomis.Kelemahan penelitian ini adalah skrining dilakukan hanya sekali, seharusnya dilakukan pemeriksaan ulangan untuk menghindari bias pemeriksaan. Skrining sebaiknya dikombinasi dengan alat skrining yang lain. Skrining pada subjek yang dinilai meragukan dalam penilaian harus dilakukan ulangan pemeriksaan 1-2 minggu kemudian setelah pemeriksaan pertama untuk memastikan adanya keterlambatan perkembangan.

\section{SIMPULAN}

Berdasarkan hasil penelitian yang dilakukan peneliti, didapatkan perkembangan sosial yang tidak sesuai pada anak usia 3-6 tahun tanpa pendidikan usia dini $(73,5 \%)$ lebih banyak dibandingkan perkembangan sosial yang sesuai pada anak usia 3-6 tahun tanpa pendidikan usia dini $(26,5 \%)$. Perkembangan sosial yang sesuai pada anak usia 3-6 tahun dengan pendidikan usia dini $(64,7 \%)$ lebih banyak dibandingkan perkembangan sosial yang tidak sesuai pada anak usia 3-6 tahun dengan pendidikan usia dini $(35,3 \%)$, maka pada hasil uji Chi-Square nilai $\mathrm{p}$ didapatkan sebesar $0,002(\mathrm{p}<0,05)$. Hasil analisis tersebut dapat disimpulkan terdapat perbedaan yang signifikan antara perkembangan sosial pada anak usia 3-6 tahun dengan pendidikan usia dini dan tanpa pendidikan usia dini di Kecamatan Peterongan Jombang, yaitu lebih baik yang mengikuti pendidikan usia dini.

\section{DAFTAR PUSTAKA}

Ardita V., Kadir A., \& Askar M., 2012.Deteksi Perkembangan Anak Berdasarkan DDST di RW I Kelurahan Luminda Kecamatan Wara Utara Kota Palopo.Vol. 1(2).

BKKBN 2014.Menjadi Orangtua Hebat dalam Mengasuh Anak (Usia 0 - 6 Tahun).ISBN : 978-602-8068-87-1

Chamida N.A., 2012. Deteksi Dini Gangguan Pertumbuhan dan Perkembangan Anak

Dahlan M.S., 2013. Besar Sampel Dan Cara Pengambilan Sampel dalam Penelitian Kedokteran dan Kesehatan.Jakarta : Salemba Medika

Darsana W., 2012. Hubungan stimulasi kecerdasan multipel dengan perkembangan personalsosial anak usia pra sekolah.http:// darsananursejiwa.blogspot.com/2012/01/ hubunganstimulasi-kecerdasanmultipel. html. Diakses 9 Januari 2016

Delfita R., 2011. Meningkatkan Kemampuan Berbahasa Anak Melalui Permainan Gambar Dalam Bak Pasir di Taman KanakKanak Bina Anaprasa Mekar Sari Padang. Jurnal Pesona PAUD. Vol 1(1). 
Departemen Kesehatan RI 2007. Pedoman Pelaksanaan Stimulasi, Deteksi dan Intervensi Dini Tumbuh Kembang Anak Ditingkat Pelayanan Kesehatan Dasar. Dinas Kesehatan Kabupaten Jombang

Diana F.M., 2010. Pemantauan Perkembangan Anak Balita. Jurnal Kesehatan Masyarakat. Vol. 4 (2).

Dinas kesehatan Jawa Timur2011. Profil Kesehatan 2011 Provinsi Jawa Timur.http://dinkes. jatimprov.go.id/userfile/dokumen/1321926974 Profil_Kesehatan_Provinsi Jawa Timur 2010. pdf Diakses pada tanggal 15 Agustus 2015

Dorlina N., 2011. Perkembangan Bahasa AnakPrasekolah. Jurnal Pembinaan dan Pengembangan Pendidikan. Vol. 08 (1).

Enung F., 2006. Psikologi Perkembangan : Perkembangan Peserta Didik. Bandung : CV Pustaka Setia

Gultiano S.A., \& King E.M., 2006. A Better Start in Life : Evaluation Result from an Early Childhood Development Program. Philippine Journal of Development Number 61, First and Second Semesters 2006. Volume XXXIII, Numbers $1 \& 2$

Halimah N., \& Kawuryan F., 2010.Kesiapan Memasuki Sekolah Dasar Pada Anak yang Mengikuti Pendidikan TK dengan yang Tidak Mengikuti Pendidikan TK di Kabupaten Kudus.Jurnal Psikologi Universitas Muria Kudus Vol. 1(1).

Hastuti D., Alfiansari.,\& Chandriyani., 2010. Nilai Anak, Stimulasi Psikososial, Dan Perkembangan Kognitif Anak Usia 2-5 Tahun Pada Keluarga Rawan Pangan Di Kabupaten Banjarnegara, Jawa Tengah. Jurnal Ilmiah Keluarga dan Konseling. Vol. 3 (1): 27-34

Ikalor A., 2013.Pertumbuhan dan Perkembangan. Jurnal Pertumbuhan dan Perkembangan. Vol. 7(1): 1-6.
Kusbiantoro D., 2015. Pertumbuhan Dan Perkembangan Anak Usia Prasekolah di Taman Kanak-Kanak Aba 1 Lamongan. Surya.Vol.7(1).

Martani W., 2012. Metode Stimulasi dan Perkembangan Emosi Anak Usia Dini. Jurnal Psikologi. Vol. 39 (1): 112 - 120

Mayar F., 2013. Perkembangan Sosial Anak Usia Dini Sebagai Bibit Untuk Masa Depan Bangsa. Jurnal Al-Ta'lim, Jilid 1, Nomor 6 November 2013, hlm. 459-464

Novianti R., Puspitasari E., \& Chairilsyah D., 2012. Pemetaan Kemampuan Guru Paud Dalam Melaksanakan Asesmen Perkembangan Anak Usia Dini di Kota Pekanbaru. Jurnal SOROT. Vol 8 (1): 1 - 104

Retnowati Y., 2008. Pola Komunikasi Orangtua Tunggal dalam Membentuk Kemandirian Anak (Kasus di Kota Yogyakarta).Jurnal Ilmu Komunikasi. Vol.6 (3).

Setyaningrum S.R., Triyanti.,\& Indrawani Y.M., 2014. Pembelajaran di Pendidikan Anak Usia Dini Dengan Perkembangan Kognitif pada Anak. Jurnal Kesehatan Masyarakat Nasional Vol.8, No. 6.

Siti M., 2012. Peningkatan Kompetensi Sosial Anak Usia Dini Dengan Metode Bermain. Jurnal Pendidikan dan Kebudayaan, Vol. 18 (1)

Sulistiani W., 2009. Penerapan Metode Bermainuntuk Meningkatkan Kemampuan Sosial AnakUsia Dini. Jurnal Ilmiah Psikologi dan Psikologi KelautanKemaritiman.Vol. 3(2).

UNICEF Indonesia 2012.Pendidikan \& Perkembangan Anak Usia Dini. http:// www.unicef.org/indonesia/id/A3___B Ringkasan_Kajian_Pendidikan.pdf Diakses pada tanggal 15 Agustus 2015 